\title{
The relationship between Covid-19 related anxiety and health anxiety: The mediating role of physical concern component
}

\author{
Mohammad Javad Shabani ${ }^{1}$, Hamid Mohsenabadi ${ }^{1}$, Banafsheh Gharraee ${ }^{2}$, Iman Taghizadeh \\ Firoozjaie $^{3}$
}

1-Student Research Committee, Department of Clinical Psychology, Iran University of Medical Sciences, Tehran, Iran.

2- Associate Professor, Department of Clinical Psychology, Iran University of Medical Sciences, Tehran, Iran (Corresponding Author). E-mail: Gharraee.b@iums.ac.ir

3- MSc, Department of Medical Surgical Nursing, Golestan University of Medical Sciences, Golestan, Iran.

Received: 26/10/2021 Accepted: 22/12/2021

\begin{abstract}
Introduction: Current models show the anxiety sensitivity physical concerns as a fundamental variable related to the psychological consequences of the Covid-19 pandemic.
\end{abstract}

Aim: This study aimed to determine the relationship between COVID-19 related anxiety and health anxiety mediated by the physical concern component during the Covid-19 pandemic.

Method: This study was a descriptive cross-sectional study conducted online. For this purpose, 554 adults in Tehran were assessed anonymously by convenience sampling methods using an online questionnaire from 21 June to 5 July 2020. The instruments of this study included the Corona Anxiety Index (CAI), Health Anxiety Inventory (SHAI), and Anxiety Sensitivity Index (ASI-3). The collected data were analyzed using the Pearson correlation method and structural equations by SPSS software version 25 and LISREL software version 8.80.

Results: The age range of participants was between 18 and 65 years, with a mean and standard deviation of $38.03 \pm 12.21$. The results of the Pearson correlation showed that the components of physical concern and health anxiety have a positive and significant relationship with COVID-19 related anxiety $(\mathrm{P}<0.05)$. The results of structural equations showed that there is a significant direct path from health anxiety to COVID-19 related anxiety. Also, a significant indirect pathway from health anxiety to COVID-19 related anxiety mediates the physical concern component with a coefficient of $0.16 \%$.

Conclusion: In the Iranian sample, the physical concern component mediates the relationship between health anxiety and COVID-19 related anxiety. These findings can help in effective prevention and explain the psychological effects of the Covid-19 pandemic.

Keywords: COVID-19, Anxiety sensitivity, Physical concern, Health anxiety

\footnotetext{
How to cite this article: Shabani MJ, Mohsenabadi H, Gharraee B, Taghizadeh Firoozjaie I. The relationship between Covid-19 related anxiety and health anxiety: The mediating role of physical concern component. Shenakht Journal of Psychology and Psychiatry. 2022; 8 (6): 138-150 . URL: http://shenakht.muk.ac.ir/article-1-1315-en.pdf
}

Copyright ( 2018 the Author (s). Published by Kurdistan University of Medical Sciences. This is an open access article distributed under the terms of the Creative Commons Attribution-Non Commercial License 4.0 (CCBY-NC), where it is permissible to download, share, remix, transform, and buildup the work provided it is properly cited. The work cannot be used commercially without permission from the journal. 


\title{
بررسى رابطدى اضطراب ناشى از كوويد-19 و اضطراب سلامت: نقش ميانجى مؤلفهى نكرانى جسمانى
}

\author{
محمد جواد شعبانى'، حميد محسن آبادى'، بنفشه غرايى'، ايمان تقى زاده فيروزجايى”
}

1. كميته تحقيقات دانشجويى، كروه روانشناسى بالينى، دانشكاه علوم يزشكى ايران، تهران، ايران.

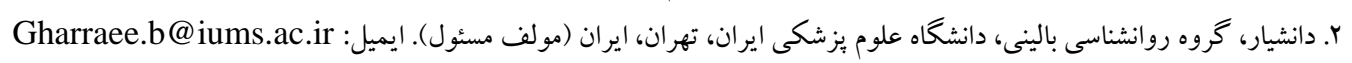

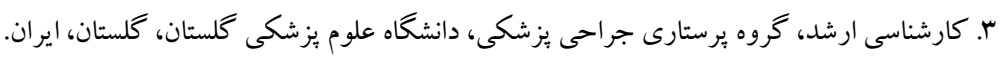

مقدمه: مدلهاى فعلى مؤلفهى نخرانى جسمانى حساسيت اضطر ابى را به عنوان متغيرى اساسى مر تبط با يِامدهاى روانشناختى ناشى از

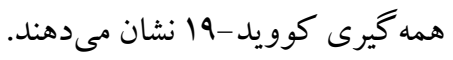

هدف: يزوهش حاضر با هدف تعيين رابطهى اضطراب ناشى از كوويد-19 و اضطراب سلامت با ميانجى گرى مؤلفهى نكرانى جسمانى در طول پياندمى كوويد-19 انجام شد.

روش: اين مطالعه از نوع يزوهش هاى توصيفى - مقطعى و دادهها به صورت ايترنتى جمع آورى شد. بدين منظور نها نفر از بزر كسالان

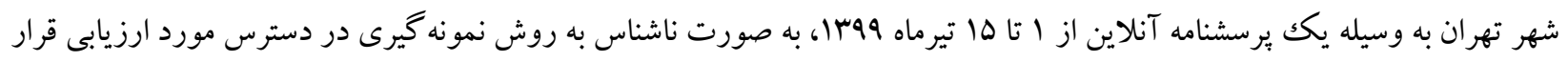

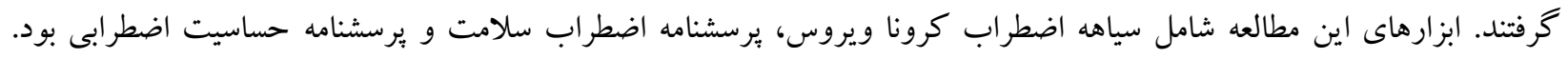

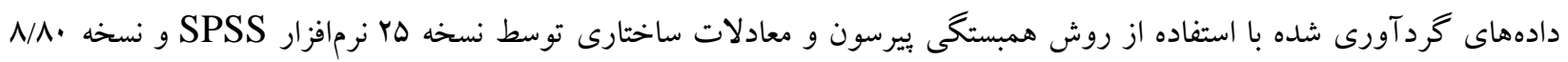
نرمافزار ليزرل تجزيه و تحليل شدند.

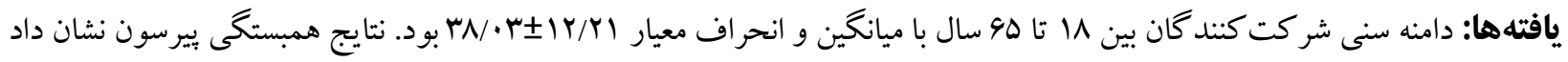

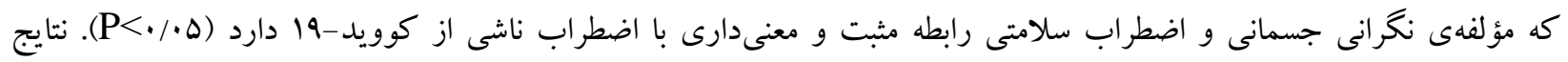
معادلات ساختارى نشان داد مسير مستقيم معنادارى از اضطراب سلامت به اضطراب ناشى از كوويد-19 برقرار است همجنين مسير

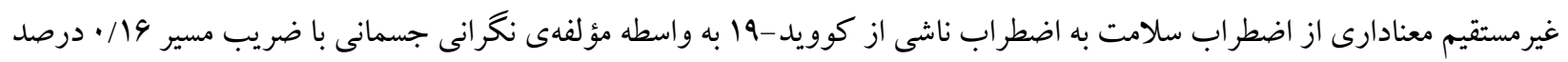
برقرار است.

نتيجه كيرى: مؤلفهى نخر انى جسمانى ارتباط بين اضطراب سلامتى و اضطراب ناشى از كوويد-19 رادر نمونهى ايرانى ميانجى گرى

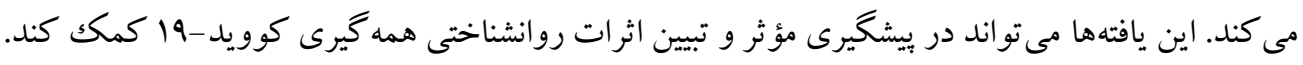
كليدوازهها: كوويد-9 1، حساسيت اضطرابى، مؤلفهى نكر انى جسمانى، اضطراب سلامت 
در يكك بررسى سيستماتيكك از بو مطالعه انجام شده در

طول همه گيرى كوويد-91، شيوع علائم اضطراب (سب/٪)

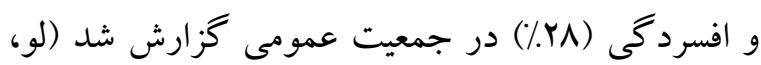

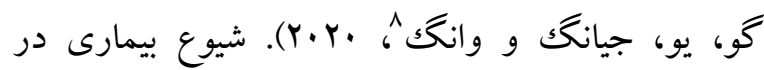
كستردگى كوويد-19 همانند ياندمىهاى گذشته مى تواند به تشديد اختلالات روانى نيز منجر شود كه در آن افراد

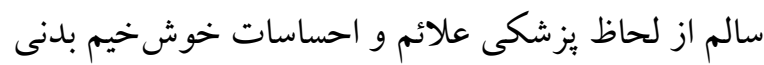

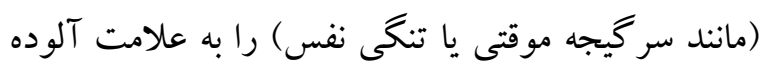
بودن با ويروس تفسير مى كنند و باعث اضطراب سلامتى ج، گوش به زنكى و افزايش درگيرى در رفتارهاى

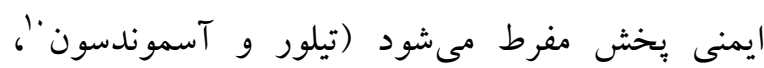

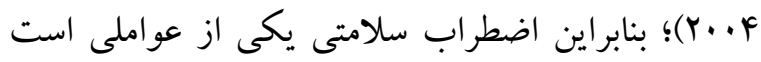

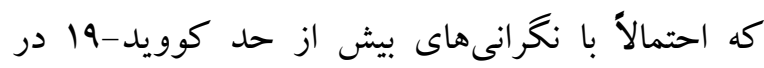
ارتباط است (تول، باربانو، اسكامالدو، ريجموند، ادموندز،

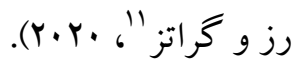

تحقيقات در مورد ساختار اضطراب سلامتى نشان مىدهد كه با تخمين بيش از حد احتمال ابتلا به بيمارى و درك هك اغراقآميز از داشتن يكك بيمارى جدى مرتبط است

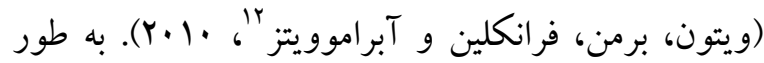
خاص، سر مقالههاى اخير بيشنهاد كردهاند كه شيوع كوويد-19 مىتواند باعث اضطراب و رنج روانى فزاينده بيماران مبتلا به وسواس فكرى عملى (فاينبر گك، ون

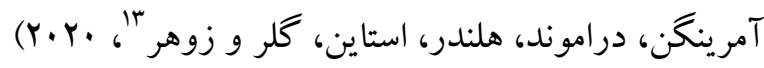

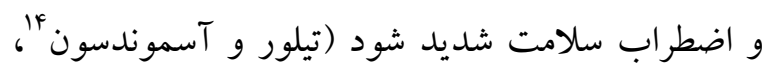
(Y.Y.Y). به همين ترتيب، افراد با اضطراب سلامتى شديد

\footnotetext{
8 - Luo, Guo, Yu, Jiang \& Wang

9 - Health anxiety

${ }^{10}$ - Taylor \& Asmundson

11- Tull, Barbano, Scamaldo, Richmond, Edmonds, Rose \& Gratz

${ }^{12}$ - Wheaton, Berman, Franklin \& Abramowitz

${ }^{13}$ - Fineberg, Van Ameringen, Drummond, Hollander, Stein, Geller \& Zohar

${ }^{14}$ - Taylor \& Asmundson
}

بيمارى كرونا ويروس جديد' (كوويد-هوا) اولين بار در ووهان جين كشف شد و از آن زمان به بعد به عنوان يكك همه گيرى جهانى اعلام شده است (مراكز كنترل و ور

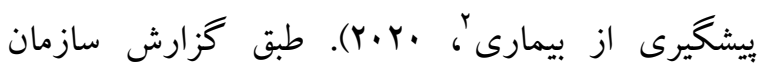

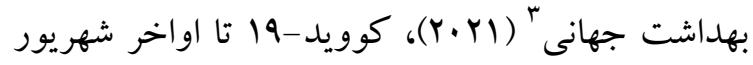
Flf.. F/V ميليون نفر مرگك و مير داشته است. اخرجه اثرات

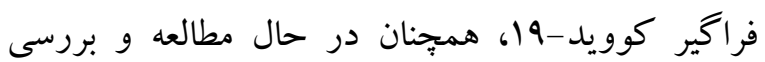
است؛ اما ويروس در حال حاضر با گسترش روزافزون در سراسر جهان باعث ايجاد اختلالات عمده در جامعه، تحولات اقتصادى و بهداشت عمومى شده است (كروبر،

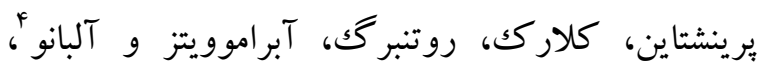
(Y.Y. مىدهند كه اثرات منفى قابل توجهى بر سلامت روان و افزايش بيريشانى روانى در جمعيت عمومى به دليل كوويد-19 وجود دارد (دوان و زومّ، .Y.Y.Y) كه از جمله آن مىتوان به تنهايى و انزواى بيشتر به دليل فاصله

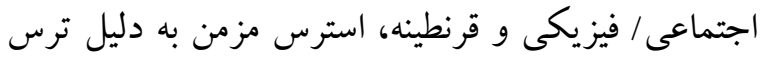
از سرايت عفونت به خود يا عزيزان و بى ثباتى اقتصادى به دليل از دست دادن شغل يا تعطيلى مشاغل را اشاره كرد

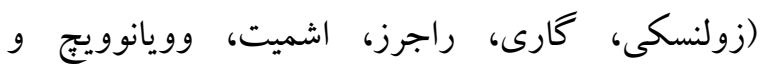

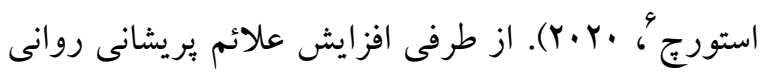

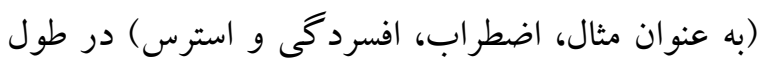

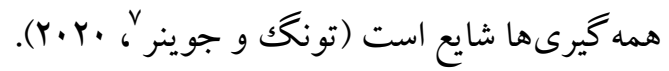

\footnotetext{
1. Coronavirus disease

2. Centers for Disease Control and Prevention

3 - World Health Organization

4- Gruber, Prinstein, Clark, Rottenberg, Abramowitz \& Albano

5 - Duan \& Zhu

${ }^{6}$ - Zvolensky, Garey, Rogers, Schmidt, Vujanovic \& Storch

${ }^{7}$ - Twenge \& Joiner
} 
جسمانى و اضطراب سلامتى را با ترس از بيمارى در

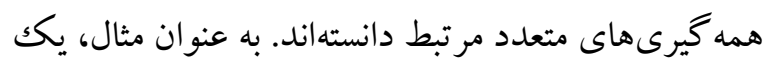
مطالعه آمريكايى بر روى M M دانشجو در زمان شيوع بيمارى زيكا، ارتباط معنىدارى بين اضطراب بيمارى، مؤلفهى نكر انى جسمانى و اضطر اب ناشى از زيكا را نشان

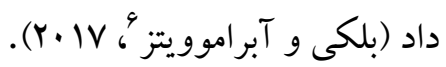

علاوهبر اين اخيراً مكك كى و همكارانش در سال .r.r.r. ارتباط معنادارى بين مؤلفهى نگر انى جسمانى و اضطراب

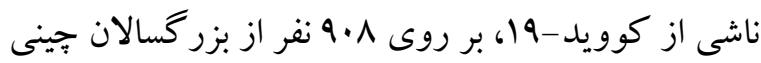

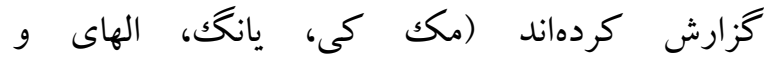

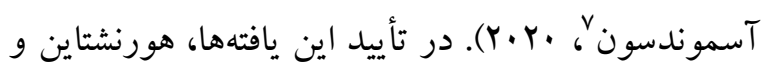
همكاران (Y.19) گزارش دادند كه اضطراب سلامت با جستجوى بيشتر مراقبتهاى بزشكى عمومى در 4 ماه كذشته در ميان افرادى كه سطوح بالايى از حساسيت اضطرابى را تجربه مى كنند، ارتباط دارد (هورنشتاين،

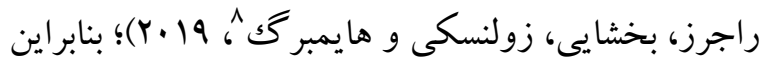
بنابراين براساس يافتهاى اين مطالعات مىتوان جنين بيشنهاد داد كه رابطه بين اضطراب سلامتى و اضطراب ناشى از كوويد-19 مىتواند توسط مؤلفهى نگرانى جسمانى تقويت شود.

ئزوهش حاضر با هدف تعيين رابطهى اضطراب ناشى از كوويد-19 و اضطراب سلامت با ميانجى گرى مؤلفهى نخر انى جسمانى در نمونه بزر گسالان ساكن شهر تهران در طول باندمى كوويد-19 انجام شد و تلاشى در جهت كسترش يافتهاى تحقيقات همه گيرى قبلى است. از اين رو براساس مطالعات قبلى فرض شد كه با كنترل سن، جنس، وضعيت تأهل، سطح تحصيلات و وضعيت شغلى؛ الف) نمره مؤلفهى نخرانى جسمانى، اضطراب ناشى از

${ }^{6}$ - Blakey \& Abramowitz

7- McKay, Yang, Elhai \& Asmundson

${ }^{8}$ - Horenstein, Rogers, Bakhshaie, Zvolensky \& Heimberg
ممكن است بيشتر تحت تأثير كوويد-19 قرار بـيرند اين در حالى است كه نكرانى درباره سلامتى خود تا حدودى

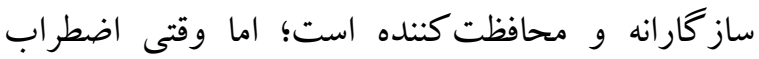
مزمن و بيش از حد باشد، مىتواند مشكلساز شود

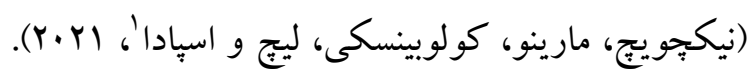

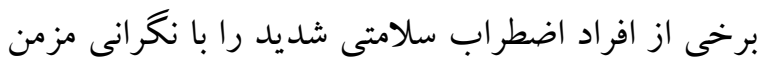
در مورد ابتلا به يكك بيمارى جدى، جـك كردن مكرر علائم بدنى بيمارى، مراجعهاى مكرر به درمانگاههاى يزشكى براى كسب اطمينان از سلامتى و اجتناب از درمانگاههاى بزشكى تجربه مى كنند (ويتون، مسنر و و برى

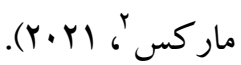
يكى ديخر از عواملى كه در همه گيرى ترس و اضطراب ناشى كوويد-19 مؤثر است، مؤلفهى نخرانى جسمانى

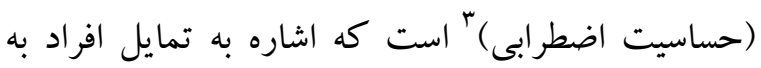
تفسير نادرست حسهاى بدنى خوشىخم (به ويزه در

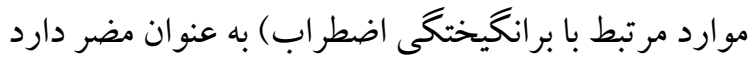

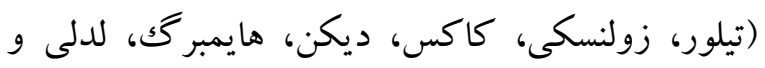

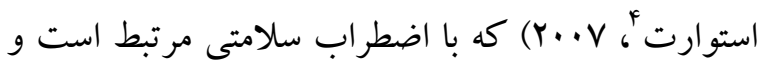

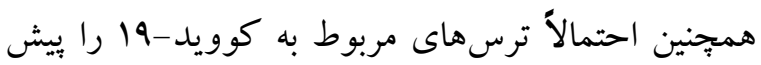
بينى مى كند. به عنوان مثال، افرادى با سطح بالاى نخرانى

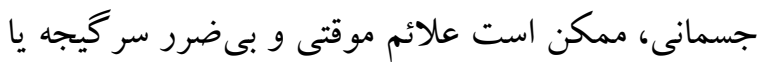
سوءهاضمه را فاجعهسازى كنند و آن را نشانههاى وجود كوويد-19 1، تفسير كنند. جنين واكنشهايى مىتواند راه انداز اضطراب و رفتارهاى ايمنىبخش افراطى مرتبط با سلامتى (مانند مراجعه به بيمارستان و درمانگگاههاى

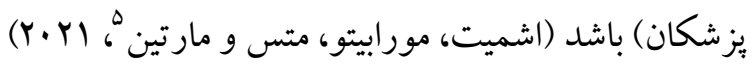
(Y.Y. (Y. در واقع، نتايج تحقيقات بيشين مؤلفهى نكرانى

\footnotetext{
1. Nikcevic, Marino, Kolubinski, Leach \& Spada

2 - Wheaton, Messner \& Marks

${ }^{3}$ - Physical Concerns Subscale of the Anxiety Sensitivity

4- Taylor, Zvolensky, Cox, Deacon, Heimberg, Ledley \& Stewart

5 - Schmidt, Morabito, Mathes \& Martin
} 
از نسخه هץ نرمافزار SPSS، نسخه •^/^ نرمافزار ليزرل تجزيه و تحليل شد.

ابز ار

فرم مشخصات دموكرافيك: اين فرم داراى برسشهايى در زمينه سن و جنس و ميزان تحصيلات و وضعيت تأهل است كه توسط شر كت كنند كان تكميل شد. سياهه اضطراب كرونا ويروس': اين ابزار در ابتدا توسط

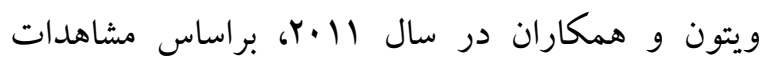

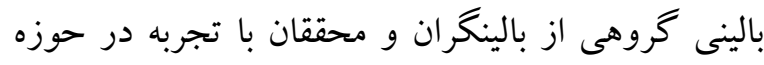
ارزيابى و معالجه افراد مبتلا به اختلالات اضطرابى و جسمى طراحى شده است. اين برسشنامه شامل ·. سؤال است كه باسخدهند كان توافق خود را با هر سؤال در مقياس ه نقطهاى از · (بسيار كم) تا ث (اخيلى زياد)" ارزيابى مى كنند. در ابتدا براى ارزيابى نخر انىهاى افراد در مورد شيوع آنفولانزاى H1N1، احتمال ادراكك شده ابتلا به آنفلوانزاى H1N1، ادراك شيوع شدت عفونت، اجتناب از مكانها و افراد خاص، استفاده از رفتارهاى ايمنى و ميزان قرار كرفتن در معرض اطلاعات ساخته شده است (ويتون، آبراموويتز، برمن، فابريكانت و و ورئ

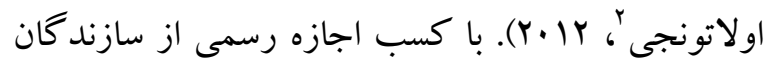
آن توسط گروه ئزوهشى، اين ابزار براى استفاده در ارتباط با ويروس كوويد-19 تطبيق داده شده است. آلفاى كرونباخ آن در مطالعه اصلى قابل قبول، هـ/A=/ به دست آمده است. در مطالعه شعبانى و همكاران (در حال انتشار)، براى نسخه فارسى سياهه اضطراب كرونا

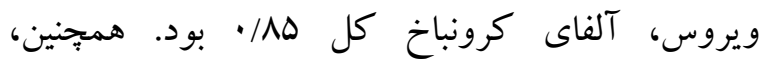
مشخصات روانسجى آن براى جمعيت ايرانى قابل قبول
كوويد-19 را بيشبينى مى كند؛ ب) نمره اضطراب سلامت، اضطراب ناشى از كوويد-19 را بيشبينى مى كند؛ و ج) نمره مؤلفه نخرانى جسمانى، نقش

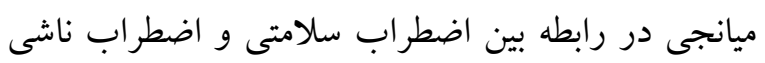

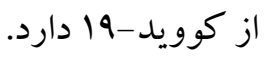

\section{روش}

يزوهش حاضر به روش توصيفى- مقطعى از نوع همبستكى انجام شد. افراد مورد مطالعه از ميان كليه جمعيت بزر گسال ساكن شهر تهران، به روش نمونه گيرى در دسترس و به صورت آنلاين از طريق شبكههاى اجتماعى (اينستاگر ام، واتس آب) انجام شد. تعداد نمونه

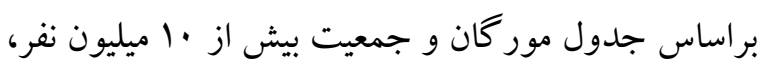
حداقل تعداد هیץ نفر محاسبه شد. معيارهاى ورودد براى شركت كنند گان شامل: حداقل سن 11 و حداكثر 90 سال، تسلط به زبان فارسى، ساكن شهر تهران، توانايى خواندن و نوشتن و اعلام رضايت آكاهانه براى شركت در مطالعه بود. عدم تمايل به تكميل برسشنامه آنلاين و

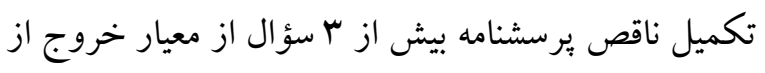
يثوهش بود. در مجموع براساس معيارهاى ورود و

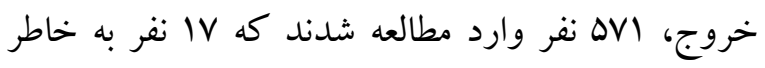
تكميل ناقص :برسشنامه از مطالعه خارج شدند و و شركت كننده داوطلب شدند تا از طريق يك يرسشنامه آنلاين كه از طريق شبكهاى اجتماعى (اينستاكرام، واتس آبٍ) ارسال شده است، در اين مطالعه شركت كنند.

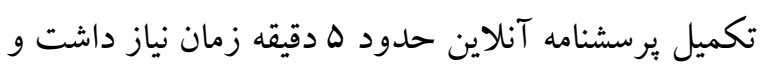
همه شركت كنند كان برسشنامه را به صورت ناشناس تكميل كردند. جمع آورى داده ها از ا تير لغايت همان

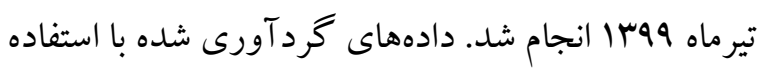

1. COVID-19 Anxiety Inventory (CAI)

${ }^{2}$ - Wheaton, Abramowitz, Berman, Fabricant \& Olatunji 
تا F = خيلى زياد نمره كذارى مىشوند و نمره بالاتر نشان دهندهى حساسيت اضطرابى بالاتر است. دامنه نمرات آن

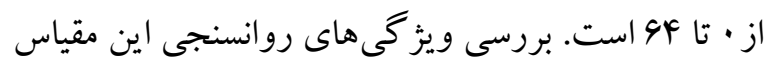

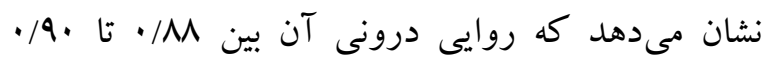
است. بايايى به روش باز آزمايى بعد از دو هفته له · • و در

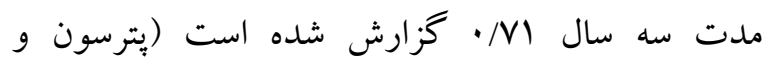

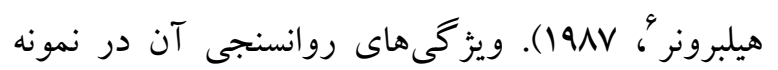
ايرانى نشان داد كه همسانى درونى براى مقياس كلى برابر

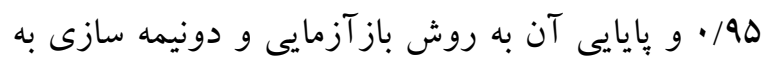
ترتيب برابر سو/ • و 9V/ • بدست آمد (نريمانى و شربتى،

(I)qp

\section{يافته ها}

از مجموع لها نفر شركت كننده در اين تحقيق 94 نفر

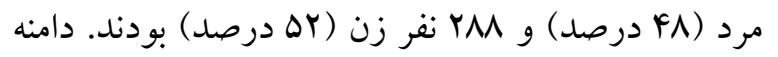

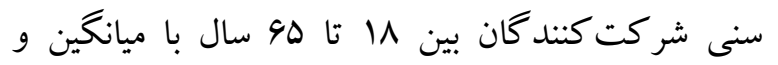
انحراف معيار |r/Y|r世

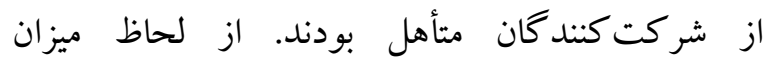
تحصيلات شركت كنند گان ·r نفر (1/ د/4 درصد) داراى مدرك كمتر از دييلم، 1.4 نفر (19/1 درصد) داراى مدرك دييلم، MrV نقر (KY/A درصد) داراى مدرك ليسانس و 191 نفر (MF/D درصد) داراى مدركك فوقليسانس و بالاتر بودند. يافتهاى توصيفى مربوط به

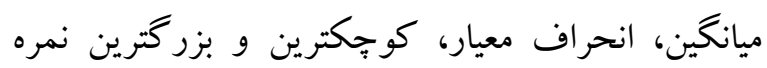
مربوط به متغيرهاى يثوهش در جدول الرائه شده است.

${ }^{6}$ - Peterson \& Heilbronner
ارزيابى شده است (شعبانى، محسن آبادى، غرايى،

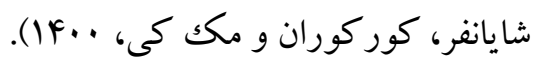
يرسشنامه اضطراب سلامت'؛ اين آزمون توسط

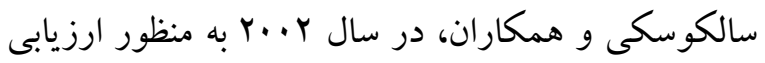
اضطراب سلامت (مستقل از وضعيت سلامت جسمانى) ساخته شد. يكك شاخص خودسنجى و داراى ل1 ماده و r عامل به اين شرح است: احتمال بيمارى، بيامدهاى منفى بيمارى و اشتغال ذهنى با بيمارى است. در هر سؤال عبارت مطرح شده است كه آزمودنى مىبايست يكى از آنها را انتخاب نمايد. عبارات مذكور به صورت صفر تا r نمره گذارى مىشود. روايى و بايايى اين مقياس به روش آلفاى كرونباخ برابر 191 • است (سالكوسكيس،

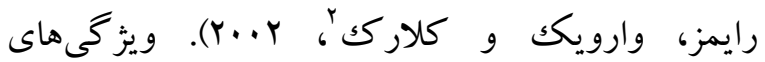
روانسنجى اين مقياس براى نمونه ايرانى به اين صورت

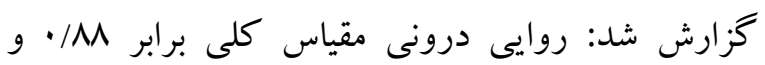
بايايى كل مقياس از طريق محاسبهى آلفاى كرونباخ

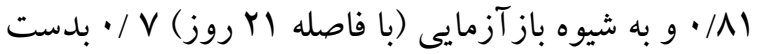
آمده است (يناهى، اصغرى مقدم، شعيرى و اقتدار نزاد، .$(1) \wedge 9$

يرسشنامه حساسيت اضطرابح"! اين برسشنامه توسط ريس و ويترسون در سال 1919 تدوين شد (ريس، هيترسون، كورسكى و مكك نالى '، 1919) و ترس فرد را از علائم

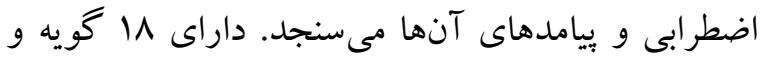
سه عامل؛ نكرانى جسمانى، ترس از كز كارى كنترل شناختى و ترس از مشاهده واكنشهاى اضطرابى ران

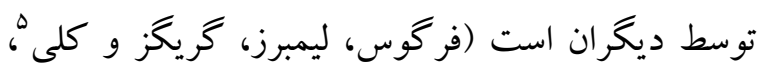

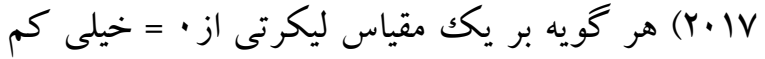

1- Short Health Anxiety Inventory (SHAI)

${ }^{2}$ - Salkovskis, Rimes, Warwick \& Clark

3 - Anxiety Sensitivity Index-3 (ASI-3)

${ }^{4}$ - Reiss, Peterson, Gursky \& McNally

5 - Fergus, Limbers, Griggs \& Kelley 
جدول ا يافتهاى توصيفى مربوط به متغيرهاى بثروهش

\begin{tabular}{|c|c|c|c|c|}
\hline بزر كترين نمره & كوجكترين نمره & انحر اف معيار & ميانكَين & متغير \\
\hline$\Delta F$ & 1 & $V / F V$ & $r \cdot / v \cdot$ & اضطراب سلامت \\
\hline rF & . & $\Delta / \Delta V$ & $1 . / 9$ & مؤلفهى نكر انى جسمانى \\
\hline r. & ir & $\Delta / \cdot F$ & $r \cdot / r \Delta$ & اضطراب ناشى از كوويد-19 \\
\hline
\end{tabular}

نخرانى جسمانى است. جدول Y ماتريس ضريب

نتايج يافتهاى توصيفى جدول ا نشان مىدهد از ميان همبستخى بين متغيرهاى بثزوهش را نشان مى دهد.

مقياس هاى بزوهش، بيشترين ميانگين مربوط به اضطراب ناشى از كوويد-19 و كمترين ميانگين مربوط به مؤلفهى

\begin{tabular}{|c|c|c|c|}
\hline \multicolumn{4}{|c|}{ جدول r ضرايب همبستغى بين متغير هاى يزوهش } \\
\hline$r$ & $r$ & 1 & متغير \\
\hline & & - & 1- اضطراب سلامت \\
\hline & - & $\cdot / \Delta \mathrm{V}$ & r - - مؤلفهى نكر انى جسمانى \\
\hline- & $\cdot / 09$ & $\cdot / \Delta F$ & | r- اضطر اب ناشى از كوويد-19 \\
\hline
\end{tabular}

اضطراب ناشى از كوويد-19 مورد بررسى قرار كرفت. در ابتدا بيشفرض هاى الكويابى معادلات ساختارى شامل سطح دادهها براى تمام متغيرها فاصلهاى باشد، نرمال بودن دادهها، عدم وجود دادههاى يرت، خطى بودن و عدم وجود همخطى جند گانه بررسى شد كه مفروضهها رعايت شده بود. شاخصهاى برازندگى در نتيجه آزمون مدل بيشنهادى در جدول r نشان داده شده است.
همانطور كه در جدول Y مشاهده مىشود، ضريب همبستخى بين اضطراب سلامت با اضطراب ناشى از كوويد-19 (r=•/DF) اضطر اب سلامت با مؤلفهى نكرانى جسمانى (r=•/OV) و مؤلفهى نخر انى جسمانى با اضطراب

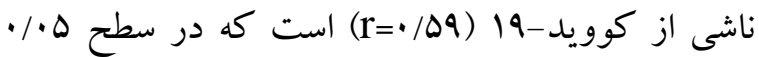
معنى دار هستند. با توجه به اينكه ماتريس همبستكى بين متغيرهاى بزٔوهش برقرار بود، در همين راستا نقش ميانجى مؤلفهى نخرانى جسمانى در رابطه بين اضطراب سلامت و ونسي

جدول ب شاخصهاى برازش مدل ميانجى مؤلفهى نكرانى جسمانى در رابطه بين اضطراب سلامتى و اضطراب ناشى از كوويد-19

\begin{tabular}{|c|c|c|c|}
\hline نتيجه & دامنه قابل قبول & مقدار & 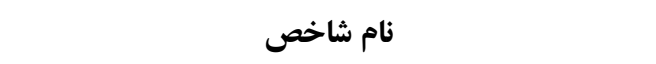 \\
\hline برازش مناسب & 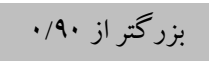 &.$/ 91$ & شاخص برازندكى تطبيقى(CFI) \\
\hline برازش مناسب & 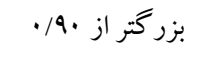 &.$/ 91$ & شاخص برازندكى فزاينده (IFI) \\
\hline 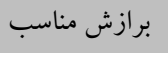 & 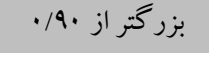 & $\cdot / 9 \vee$ & شاخص برازش هنجار شده (NFI) \\
\hline برازش مناسب & 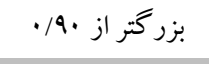 & $\cdot / 9 r$ & شاخص نيكويى برازش (GFI) \\
\hline برازش مناسب & 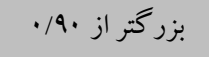 &.$/ 91$ & شاخص نيكويى برازش تعديل شده (AGFI) \\
\hline برازش مناسب & 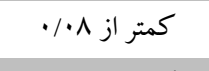 & $\cdot / \cdot 4$ & ريشه دوم بر آورد واريانس خطاى تقريب (RMSEA) \\
\hline 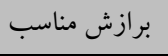 & 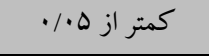 & $\cdot / \cdot F$ & شاخص ريشه ميانتين مربعات باقيمانده استاندارد شده \\
\hline
\end{tabular}




\section{(SRMR)}

در همين راستا جدول F ضرايب ركرسيونى متغيرها

نتايج جدول r نشان مىدهد كه مدل بيشنهادى از برازش سطوح معنى دارى مدل نهايى را نشان ميدهد.

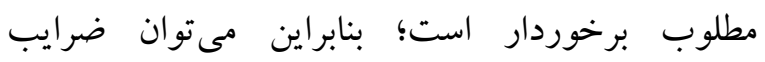

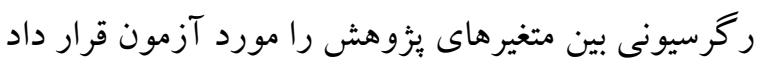

\begin{tabular}{|c|c|c|c|}
\hline \multicolumn{4}{|c|}{ جدول † ضرايب ركرسيونى و سطوح معنىدارى مدل نهايى } \\
\hline تأثير كذارى & معنى سطحى & ضأثريب & 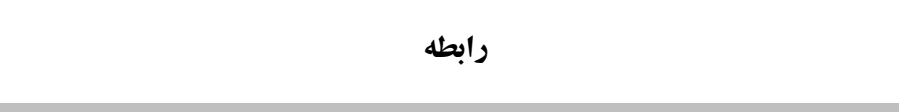 \\
\hline مستقيم & $\cdot \cdots 1$ & $\cdot / 44$ & اضطراب سلامت ٪ اضطراب ناشى از كوويد-19 \\
\hline مستقيم &.$\cdots 1$ & $\cdot / F Y$ & مؤلفه نترانى جسمانى ـ اضطر اب ناشى از كوويد-19 \\
\hline غير مستقيم & 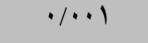 & $\cdot 199$ & اضطراب سلامت ٪ مؤلفه نكرانى جسمانى ٪ اضطراب ناشى از كوويد-19 \\
\hline
\end{tabular}

نتايج حاصل در جدول F نشان مىدهد كه متغيرهاى ميانجى گرى مؤلفه نغرانى جسمانى با اضطراب ناشى از

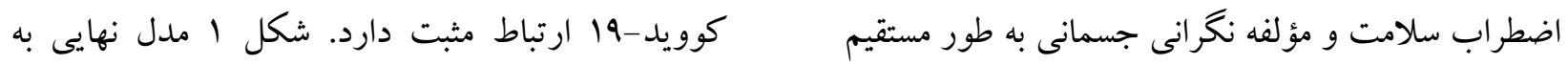

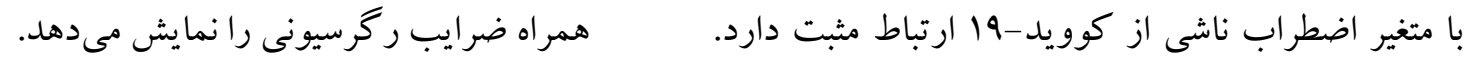
همجنين متغير اضطراب سلامت به طور غير مستقيم و با لابل

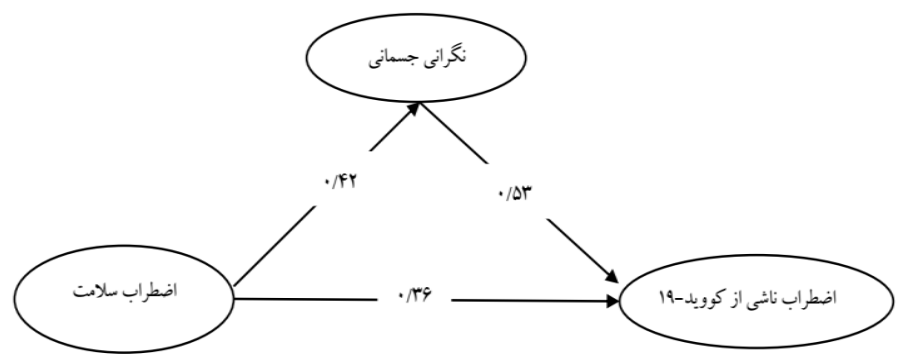

شكل 1 مدل نهايى بيشينى اضطر اب ناشى از كوويد-19 براساس اضطراب سلامت و نكر انى جسمانى

معنىدارى داشت. همجنين يافتها از اين فرض كه خرده يزووهش حاضر با هدف تعيين رابطهى اضطراب ناشى از مقياس نغرانى جسمانى (حساسيت اضطرابى)، اضطراب

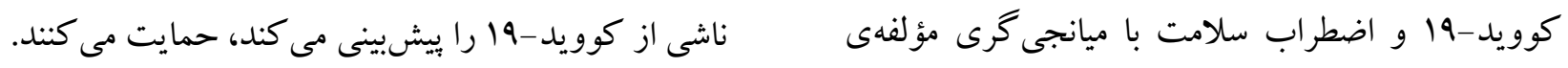

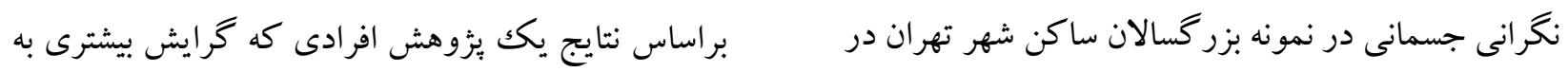

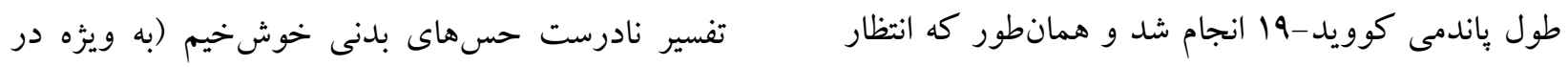

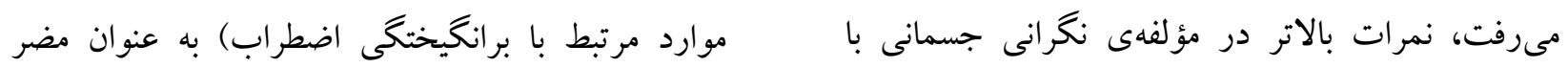

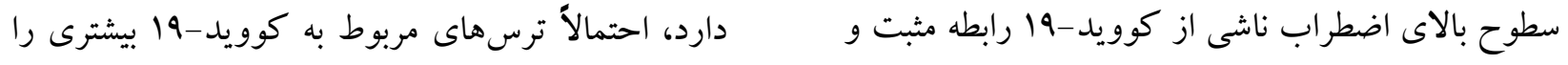


است بيمارستانها و مطب يزشكان را به عنوان منبع سرايت در نظر بحيرند؛ بنابراين، از درخواست معاينه يزشكى اجتناب كنند. از سوى ديكر، ساير افرادى كه سطوح بالايى از اضطراب سلامتى و حساسيت اضطر ابى تجربه مى كنند، تمايل دارند اطلاعات مربوط به سلامتى و اطمينان جويى را اغلب از بزشكان جستجو كنند. از اين رو، آنها ممكن است به منظور اطمينان از اينكه احساسات و تغييرات جسمانى آنها به دليل عفونت نيست، به بزشكان متعدد يا حتى به اورزانس بيمارستان مراجعه كنند و جاى تعجب نيست كه مراكز درمانى و بيمارستانها با مراجعات مكرر اين دست از افراد براى معاينات بزشكى، اصرار براى آزمايشهاى بزشكى و و

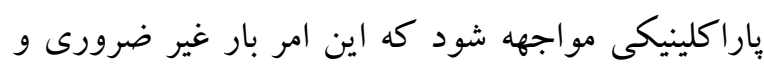
طاقت فرسايى را بر كادر بهداشت و درمان و منابع محدود آن اضافه مى كند (اسموندسون و تيلور، ·.Y.Y). نتايج يُوهش حاضر نشان داد كه خرده مقياس نخرانى جسمانى (حساسيت اضطرابى)، نقش ميانجى نيرومندى بر رابطه متغيرهاى اضطراب سلامتى و اضطراب ناشى از كوويد-19 دارد. افرادى كه اضطراب كوويد-19 بالاترى داشتند بيشتر به حساسيت اضطر ابى مبتلا بودند كه به نوبه خود با سطوح بيشتر اضطراب سلامتى همراه بود. اين

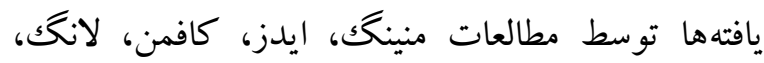

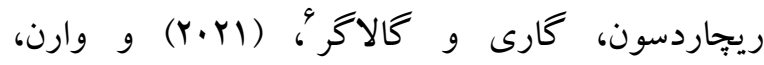

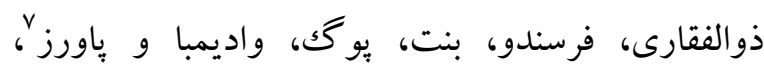

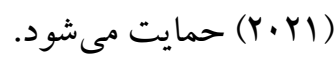

در تبيين اين نتايج همسو با تحقيقات بالا مىتوان كفت كه افرادى كه نخرانىهاى جسمانى بالايى دارند، تمايل

6- Manning, Eades, Kauffman, Long, Richardson, Garey \& Gallagher

7. Warren, Zolfaghari, Fresnedo, Bennett, Pogue, Waddimba \& Powers
تجربه مى كند و به دنبال آن اضطراب ناتوان كننده و افت عملكردهاى شناختى بيشترى را نشان مىدهند. اين رابطه همجين وقتى بيجيده تر مىشود كه به دليل دوره نهفتكى طولانى مدت ويروس (f) روزه)، اين افراد بعد از هر گونه تماس با ديخران يا محيطهاى مشكو كى، فكر مى كنند كه آلوده به ويروس هستند؛ بنابراين تا دو هفته از اضطر اب شديد و فلج كنندهاى رنج مىبرند (لاور، گرانتز،

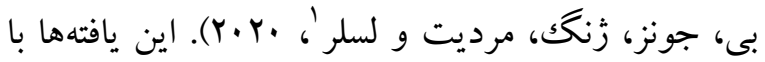
مطالعات بر روى همه گيرىهاى كذشته همجيجون ابولا (بلكى و همكاران، ها·r) زيكا (بلكى و ابرومويج،

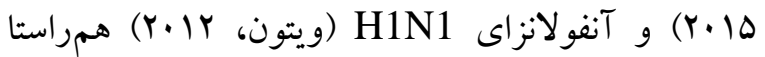
است. همجينين، مطالعات اخير كوويد-19 (خورى، وات

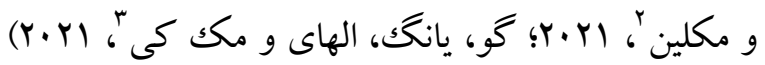
از اين نتايج حمايت مى كند. علاوه بر اين، اضطراب سلامتى نقش ويشبينى كننده نيرومندى در اضطراب ناشى از كوويد-19 دارد. براساس نتايج يُوهش حاضر بين اضطراب سلامتى، مؤلفهى نكرانى جسمانى و اضطراب ناشى از كوويد-19 رابطه معنىدار و مستقيمى وجود دارد كه همراستا با مطالعات بيشين در اين زمينه است (لندى، پياكنهام، بو كلينى،

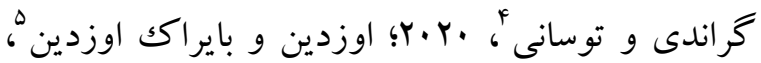
.r.r. . . اين نتايج با تحقيقات اخير ديخرى كه اين رابطه را نشان مىدهد، مطابقت دارد (خورى و همكاران،

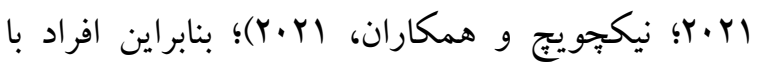
سطوح بالاى اضطراب سلامتى و حساسيت اضطرابى به روشهاى مختلفى مى توانند به اضطراب ناشى از كوويد19، ياسخ بدهند. از يكك سو، برخى از اين افراد ممكن لئن

\footnotetext{
1- lauer, Grantz, Bi, Jones, Zheng, Meredith \& Lessler

2. Khoury, Watt \& Mac Lean

${ }^{3}$ - Guo, Yang, Elhai \& McKay

4- Landi, Pakenham, Boccolini, Grandi \& Tossani

5 - Ozdin \& Bayrak Ozdin
} 
براساس نتايج مطالعه حاضر مىتوان كفت كه مؤلفهى نكرانى جسمانى مىتواند ارتباط بين اضطراب سلامتى و اضطراب ناشى از كوويد-19 را در نمونهى ايرانى ميانجى گرى كند. علاوه بر اين مطالعه راضر محدوديتهايى دارد كه بايد در نظر گرفته شود. در ابتدا، همه ابزارهاى استفاده شده براى جمع آورى اطلاعات در اين مطالعه از نوع خود گزارشى بودند. همبِنين روش نمونه گيرى اين مطالعه به دليل شرايط همه گيرى كوويد19 به صورت اينترنتى و در دسترس انجام شده كه ممكن است بسيارى از افراد به دليل عدم آشنايى با شبكههاى مجازى و يا عدم دسترسى به اينترنت در اين مطالعه شركت نكرده باشند. از آنجا كه نمونه مطالعه حاضر از جمعيت بزر گسال شهر تهران جمع آورى شده احتمالاً تعميم آن به بقيه كروههاى سنى و مناطق كشور با بهر محدوديت همراه است. علاوه بر اين، نمونه مطالعه حاضر از جمعيت عمومى و غير بالينى تشكيل شده است و اين امر تعميم نتايج اين مطالعه را به افراد و نمونهاى بالينى با ترديد روبهرو مى كند از اين رو نياز به مطالعات بيشتر با نمونه هاى بالينى احساس مىشود.

\section{سياسگزارى}

IR.IUMS.REC.1399.195 اين مطالعه با كد اخلاق حاصل طرح تحقيقاتى به شماره IVANV و با حمايت مالى

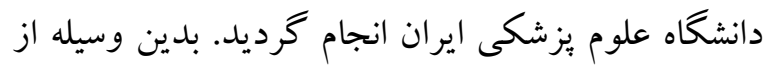
تمام شركت كنند كان اين مطالعه كه بدون همكارى آنها انجام اين مطالعه ممكن نبود كمال تشكر و قدردانى را

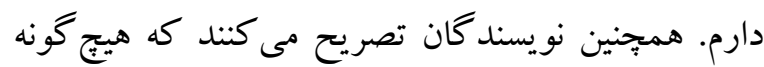
تعارض منافعى در مطالعه حاضر وجود ندارد.

\section{References}

دارند كه بيشتر به حسهاى جسمانى توجه كرده و معناى آن حسها را فاجعه بار كنند؛ زيرا تصور مى كنند كه آنها آسيبهاى قريب الوقوع مانند حمله قلبى را نشان مىدهند. در شرايط همه گيرى، مردم تشويق مىشوند علائم جسمانى خود (تب، تنكى نفس، كلودرد و سردرد) را به طور منظم ارزيابى كنند. براى افرادى كه نگر انىهاى جسمانى برجستهاى دارند، اين مى تواند جرخهاى از توجه بيشتر به احساسات بدنى را فعال كند كه منجر به افزايش اضطراب و نياز بيشتر به رفتارهاى ايمنىبخش افراطى (براى مثال، اطمينانجويى از يزشكان و مراجعات مكرر به مراكز درمانى) مىشود و به نوبه خود مىتواند

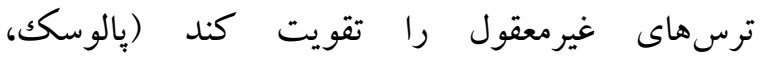

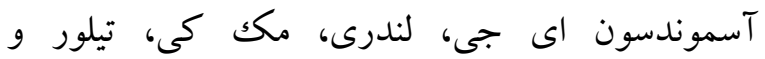

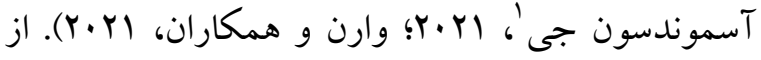
اين رو استفاده از تستهاى غربالگرى براى شناسايى افراد مبتلا به حساسيت اضطرابى مىتواند حجم قابل توجهى از مراجعات مكرر به بيمارستانها و اختلال در روند ييشخيرى و درمان به دليل اين عوامل را در وضعيت پاندمى كاهش دهد. همجنين راهبردهاى كاهش حساسيت اضطراب بالا (براى مثال، مداخلات درمان

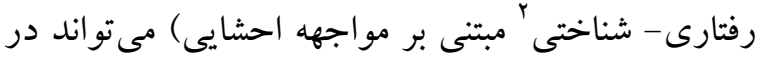
كاهش اين علائم ارزشمند باشد (خورى و همكاران، (Y.Y) تأثير احتمالى مداخلات حساسيت اضطرابى بر بيامدهاى منفى سلامت روان در دوران همه گيرى كوويد-19 مشخص شود.

\section{نتيجه كيرى}

\footnotetext{
1- Paluszek, Asmundson AJ, Landry, McKay, Taylor \& Asmundson GJ

${ }^{2}$ - Cognitive Behavioral Therapy (CBT)
} 
Asmundson GJ, Taylor S. (2020). How health anxiety influences responses to viral outbreaks like COVID-19: What all decision-makers, health authorities, and health care professionals need to know. Joumal of Anxiety Disorders, 71, 102-211.

Blakey SM, Abramowitz JS. (2017). Psychological predictors of health anxiety in response to the Zika virus. Joumal of Clinical Psychology in Medical Settings, 24(3), 270-278.

Blakey SM, Reuman L, Jacoby RJ, Abramowitz JS. (2015). Tracing "Fearbola": psychological predictors of anxious responding to the threat of ebola. Cognitive Therapy and Research, 39(6), 816-825.

Centers for Disease Control and Prevention. (2020). Coronavinus Disease 2019. Retrieved from https://www.cdc.gov/media/dpk/diseases-andconditions/coronavinus/coronavirus2020.html.

Duan L, Zhu G. (2020). Psychological interventions for people affected by the COVID-19 epidemic. The Lancet Psychiatry. Advance online publication, 7:300-302.

Fergus TA, Limbers CA, Griggs JO, Kelley LP. (2017). Somatic symptom severity among primary care patients who are obese: examining the unique contributions of anxiety sensitivity, discomfort intolerance, and health anxiety. Journal of Behavioral Medicine, 41(1):43-51.

Fineberg NA, Ameringen M, Drummond L, Hollander E, Stein D, Geller D. (2020). How to manage obsessive-compulsive disorder (OCD) under COVID-19: A clinician's guide from the International College of Obsessive Compulsive Spectrum Disorders (ICOCS) and the Obsessive-Compulsive and Related Disorders Research Network (OCRN) of the European College of Neuropsychopharmacology. Comprehensive psychiatry, 100, 152-174.

Gruber J, Prinstein MJ, Clark LA, Rottenberg J, Abramowitz JS, Albano AM, Davila J. (2020). Mental health and clinical psychological science in the time of COVID19: Challenges, opportunities, and a call to action. American Psychologist, 76(3), 409426.

Guo Y, Yang H, Elhai J, McKay D. (2021). Anxiety Regarding COVID-19 Is Related to Attentional Control: The Mediating Role of Anxiety Sensitivity. Frontiers in Psychiatry, 12, 713-279.

Horenstein A, Rogers AH, Bakhshaie J, Zvolensky MJ, Heimberg RG. (2019). Examining the role of anxiety sensitivity and intolerance of uncertainty in the relationship between health anxiety and likelihood of medical care utilization. Cognitive Therapy and Research, 43(1), 55-65.

Khoury JM, Watt MC, MacLean K. (2021). Anxiety Sensitivity Mediates Relations Between Mental Distress Symptoms and Medical Care Utilization During COVID-19 Pandemic. International Journal of Cognitive Therapy, 14, 515-536.

Landi G, Pakenham KI, Boccolini G, Grandi S, Tossani E. (2020). Health anxiety and mental health outcome during COVID-19 lockdown in Italy: the mediating and moderating roles of psychological flexibility. Frontiers in Psychology, 11, 2195.

Lauer SA, Grantz KH, Bi Q, Jones FK, Zheng Q, Meredith HR, Lessler J. (2020). The incubation period of coronavinus disease 2019 (COVID-19) from publicly reported confirmed cases: estimation and application. Annals of Internal Medicine, 172(9), 577-582.

Luo M, Guo L, Yu M, Jiang W, Wang H. (2020). The psychological and mental impact of coronavinus disease 2019 (COVID-19) on medical staff and general public-A systematic review and meta-analysis. Psychiatry research, 291, 113190.

Manning K, Eades ND, Kauffman BY, Long LJ, Richardson AL, Garey L, Gallagher MW. (2021). Anxiety Sensitivity Moderates the Impact of COVID-19 Perceived Stress on Anxiety and Functional Impairment. Cognitive Therapy and Research, 45, 689696. 
McKay D, Yang H, Elhai J, Asmundson GJ. (2020). Anxiety regarding contracting COVID-19 related to interoceptive anxiety sensations: The moderating role of disgust propensity and sensitivity. Joumal of Anxiety Disorders, 73, 102-233.

Narimani M, Sharbati A. (2015). Comparison of anxiety sensitivity and cognitive function in students with and without dysgraphia. Joumal of Leaming Disabilities, 4(4), 85-100. (In Persian)

Nikcevic AV, Marino C, Kolubinski DC, Leach D, Spada MM. (2021). Modelling the contribution of the Big Five personality traits, health anxiety, and COVID-19 psychological distress to generalised anxiety and depressive symptoms during the COVID-19 pandemic. Journal of affective disorders, 279, 578-584.

Ozdin S, Bayrak Ozdin S. (2020). Levels and predictors of anxiety, depression and health anxiety during COVID-19 pandemic in Turkish society: The importance of gender. International Journal of Social Psychiatry, 66(5), 504-511.

Paluszek MM, Asmundson AJ, Landry CA, McKay D, Taylor S, Asmundson GJ. (2021). Effects of anxiety sensitivity, disgust, and intolerance of uncertainty on the COVID stress syndrome: a longitudinal assessment of transdiagnostic constructs and the behavioural immune system. Cognitive Behaviour Therapy, 3, 191203.

Panahi S, Asghari Moghadam MA, Shaeeri MR, Eghtedar Nejhad S. (2010). Psychometric properties of a Persian version of the short form of health anxiety inventory in nonclinical Iranian populations. Quarterly of Educational Measurement, 1(2), 21-46. (In Persian)

Peterson RA, Heilbronner RL. (1987). The anxiety sensitivity index: Construct validity and factor analytic structure. Journal of Anxiety Disorders, 1(2), 117-121.

Reiss S, Peterson RA, Gursky DM, McNally RJ. (1986). Anxiety sensitivity, anxiety frequency and the prediction of fearfulness. Behaviour research and therapy, 24(1), 1-8.

Salkovskis PM, Rimes KA, Warwick H, Clark D. (2002). The Health Anxiety Inventory: development and validation of scales for the measurement of health anxiety and hypochondriasis. Psychological medicine, 32(5), 843-853.

Schmidt NB, Morabito DM, Mathes BM, Martin A. (2021). Anxiety Sensitivity Prospectively Predicts Pandemic-Related Distress. Joumal of affective disorders, 292, 660-666.

Shabani MJ, Mohsenabadi H, Gharraee B, Shayanfar F, Corcoran VP, McKay D. (2021). Psychological Predictors of Health anxiety in Response to the Coronavinus (COVID-19) Pandemic: a cross-sectional online study in Iran. Intemational Joumal of Cognitive Therapy. (In Persian)

Taylor S, Asmundson GJ. (2004). Treating health anxiety: A cognitive-behavioral approach: 1st Edition Guilford Press, New York, United States.

Taylor S, Zvolensky MJ, Cox BJ, Deacon B, Heimberg RG, Ledley DR, Stewart SH. (2007). Robust dimensions of anxiety sensitivity: development and initial validation of the Anxiety Sensitivity Index-3. Psychological Assessment, 19(2), 176.

Tull MT, Barbano AC, Scamaldo KM, Richmond JR, Edmonds KA, Rose JP, Gratz KL. (2020). The prospective influence of COVID-19 affective risk assessments and intolerance of uncertainty on later dimensions of health anxiety. Joumal of Anxiety Disorders, 75, 102290.

Twenge JM, Joiner TE. (2020). US Census Bureau-assessed prevalence of anxiety and depressive symptoms in 2019 and during the 2020 COVID-19 pandemic. Depression and anxiety, 37(10), 954-956.

Warren AM, Zolfaghari K, Fresnedo M, Bennett M, Pogue J, Waddimba A, Powers MB. (2021). Anxiety sensitivity, COVID-19 fear, and mental health: results from a United States 
population sample. Cognitive Behaviour Therapy, 50(3), 204216.

Wheaton MG, Abramowitz JS, Berman NC, Fabricant LE, Olatunji BO. (2012). Psychological predictors of anxiety in response to the H1N1 (swine flu) pandemic. Cognitive Therapy and Research, 36(3), 210-218.

Wheaton MG, Berman NC, Franklin JC, Abramowitz JS. (2010). Health anxiety: Latent structure and associations with anxiety-related psychological processes in a student sample. Journal of Psychopathology and Behavioral Assessment, 32(4), 565-574.

Wheaton MG, Messner GR, Marks JB. (2021). Intolerance of uncertainty as a factor linking obsessive-compulsive symptoms, health anxiety and concems about the spread of the novel coronavinus (COVID-19) in the United States. Journal of Obsessive-Compulsive and Related Disorders, 28, 100-605.

World Health Organization website. (2021). https://who. sprinklr. com/. Accessed April, 17.

Zvolensky MJ, Garey L, Rogers AH, Schmidt NB, Vujanovic AA, Storch EA, Smits JA. (2020). Psychological, addictive, and health behavior implications of the COVID-19 pandemic. Behaviour research and therapy, 134, 103-715. 